\title{
ANALISIS KEBIJAKAN PENGELOLAAN HASIL HUTAN BUKAN KAYU (HHBK) DI NTB DAN NTT ${ }^{1}$
}

\author{
Gatot Dwi Hendro Wibowo ${ }^{2}$
}

\begin{abstract}
This research is at aiming to study policy related to the management of Non Timber Forest Products (NTFP'S). To find the policy choice in developingNTFP'S appropriately and comply with the charasteristic of each location of research is the purpose of this study. This may be done by combaining normative and empirical legal research methods. Here, the empirical legal research method is used to help the doctrinal or normative legal research. Based on this research, in those research location are found that NTFP's, first, are not to be fully concerned yet though there is consciousness that the NTFP'S potential are adequate enough and it gives benefit as best as possible for the people particularly to them living around the forest areas. Its indicator is the NTFP's policies are not enacted in the legislation product in those regions and/or the strategis plan of regencies/cities. Second, the study result of the NTFP'smanagement has indicative value and technical academic only, has no legally binding force for their drafters and users. Threrefore, NTFP's needs the clear legal basis binding for the lawgivers and their justiciabels. Third, there are various choices of the policies in managing NTFP's needed to be enacted in the legal/policy products, among other the formation of the working groups of NTFP'S; the determining of the pavoredcommoditieshaving competitive values of the NTFP's in the region, the Formulation of Strategy, Policy and Program of the NTFP's Management in the region, and the Regulation of the Business Management of NTFP's in the Region.Fourth, there are legal opportunities to submit the revision plan to the Regulation of the Forest Minister, Number P.35/Menhut-II/2007 on the: the Forest Products of Non Timbers through the procedures or mechanism of the creation of rules and regulations.
\end{abstract}

Key Words: Non Timber Forest Products (NTFP's); policy

\footnotetext{
${ }^{1}$ Penelitian dilakukan selama 3 bulan tahun 2012 dan mendapat dukungan sepenuhnya dari International Tropical Timber Organization (ITTO) dan WWF Indonesia Program Nusa Tenggara.

2 Dosen Tetap Fakultas Hukum Universitas Mataram. Alamat Korespondensi: gatot_dh_wibowo@yahoo.co.id.
} 


\begin{abstract}
Abstrak
Penelitian ini bertujuan untuk mempelajari kebijakan yang terkait dengan pengelolaan Non Timber Forest Products (NTFP's). Tujuan dari penelitian ini adalah untuk menemukan pilihan kebijakan dalam pengembangan NTFP secara tepat dan sesuai dengan karakteristik masing-masing lokasi penelitian ini. Hal ini dapat dilakukan dengan mengkombinasikan metode penelitian hukum normatif dan empiris. Disini, metode penelitian hukum empiris digunakan untuk membantu penelitian hukum doktrinal atau normatif. Berdasarkan hasil penelitian, pada lokasi penelitian ditemukan bahwa NTFP itu, pertama, tidak sepenuhnya peduli atau belum sekalipun ada kesadaran bahwa potensi NTFP'S cukup memadai dan memberikan manfaat sebaik mungkin bagi orang-orang terutama bagi mereka yang tinggal sekitar kawasan hutan. Indikatornya adalah kebijakan NTFP itu tidak berlaku pada produk peraturan di daerah-daerah dan/atau rencana strategis kabupaten/ kota. Kedua, hasil studi manajemen, NTFP memiliki nilai indikatif dan akademik teknis saja, telah ada yang mengikat secara hukum berlaku untuk perancang dan penggunanya. Oleh karena itu, kebutuhan NTFP itu dasar hukum yang jelas mengikat bagi para pembuat hukum dan justiciabels. Ketiga, ada berbagai pilihan kebijakan dalam mengelola perlu diberlakukan dalam hukum/kebijakan produk NTFP, antara lain pembentukan kelompok kerja NTFP'S; penentuan komoditas yang disukai dan memiliki nilai kompetitif dari NTFP di kawasan itu, Penyusunan Strategi, Kebijakan dan Program Manajemen NTFP di kawasan itu, dan Peraturan Manajemen Usaha NTFP di Kawasan. Keempat, ada peluang hukum untuk mengajukan revisi terhadap Peraturan Menteri Kehutanan Nomor P.35/Menhut-II / 2007 tentang: Produk Hutan Non Timbers melalui prosedur atau mekanisme terciptanya peraturan dan regulasi.
\end{abstract}

Kata kunci: Hasil Hutan Bukan Kayu (HHBK), kebijakan

\title{
I. Pendahuluan
}

Berdasarkan Peraturan Menteri Kehutanan (Permenhut) No. P.21/Menhut-II/2009 pada lampirannya disebutkan nilai ekonomi Hasil Hutan Bukan Kayu (HHBK) di Indonesia diperkirakan mencapai 90\% dari total nilai ekonomi yang dapat dihasilkan dari ekosistem hutan. Selain itu, komoditi HHBK juga merupakan salah satu sumberdaya kawasan yang paling menyentuh kehidupan masyarakat sekitar hutan. Produk HHBK telah menjadi pemasukan sekaligus pendapatan langsung bagi pemenuhan kebutuhan banyak rumah tangga dan masyarakat di seluruh dunia.

Dalam rangka mengembangkan dan meningkatkan produksi HHBK, pemerintah pusat telah mengeluarkan beberapa kebijakan, antara lain melalui Permenhut Nomor: P.35/Menhut-II/2007 tentang Hasil Hutan Bukan Kayu dan

${ }^{3}$ Iqbal, 1993; Walter, 2001. 
P.19/Menhut-II/2009 tentang Strategi Pengembangan Hasil Hutan Bukan Kayu Nasional. Di samping itu, pemerintah juga telah menetapkan kriteria dan indikator HHBK unggulan sebagaimana tertuang dalam Permenhut Nomor: P.21/Menhut-II/2009. Kebijakan pengembangan HHBK, baik yang berasal dari dalam maupun luar kawasan hutan diharapkan mampu mengurangi ketergantungan pada hasil hutan kayu, meningkatkan pendapatan masyarakat sekitar hutan dari HHBK, menumbuhkan kesadaran masyarakat untuk memelihara kawasan hutan, meningkatkan devisa sektor kehutanan bukan kayu, dan menciptakan lapangan kerja baru di sektor kehutanan yang berasal dari komoditas HHBK. ${ }^{4}$ Selain itu, lewat pengembangan hasil hutan bukan kayu ini diharapkan terjadi optimalisasi pemanfaatan HHBK, yang meliputi jumlah jenis, bentuk, tahap pengolahan, serta mutunya. Kemudian juga diharapkan optimalisasi potensi daerah dalam pengembangan HHBK sebagai alternatif sumber pangan, sumber bahan obat-obatan, penghasil serat, penghasil getah-getahan yang dapat meningkatkan ekonomi lokal dan nasional.

Di Nusa Tenggara Barat (NTB) potensi HHBK cukup besar baik yang berada di dalam kawasan maupun di luar kawasan hutan. Berdasarkan hasil penelitian Rencana Pengelolaan HHBK di Kabupaten Lombok Utara, dan Kabupaten Lombok Tengah terdapat sejumlah komoditas yang dikembangkan oleh masyarakat. Berikut ini adalah rinciannya. Di Kabupaten Lombok Utara, potensi HHBK di dalam kawasan hutan yakni di dalam kawasan HKm sebanyak 27 komoditi dan di luar HKm sebanyak 19 komoditi. Potensi HHBK di luar kawasan hutan sebanyak 25 komoditi. Di Kabupaten Lombok Tengah, potensi HHBK di dalam kawasan hutan yakni di dalam kawasan HKm sebanyak 39 komoditi dan di luar HKm sebanyak 23 komoditi. Potensi HHBK di luar kawasan hutan sebanyak 36 komoditi. $^{5}$

Hasil kajian yang dilakukan oleh WWF tahun 2012 berupa modul pengembangan kapasitas masyarakat lokal, rencana strategis pengelolaan HHBK dan strategi pengembangan ekonomi masyarakat sebatas menjadi pedoman atau panduan bagi stakeholders di daerah sehingga hanya memiliki nilai indikatif saja, tidak memiliki kekuatan mengikat (yuridis). Dalam kaitan itu, studi ini menjadi penting dalam rangka meletakkan dasar-dasar akademik bagi lahirnya sebuah produk kebijakan yang obyektif, rasional dan responsif. Pelibatan masyarakat dan/atau stakeholder dalam proses pembentukan produk kebijakan memiliki makna yang sangat substansial karena memiliki legitimasi sekaligus keabsahan berlaku secara sosiologis.

Kajian kebijakan ini dimaksudkan untuk mengkaji peraturan perundangundangan yang dikeluarkan mulai dari tingkat pusat sampai kebijakan di tingkat daerah yang terkait dengan pengembangan HHBK. Tujuannya meliputi:

(1). Menemukan pilihan kebijakan dan dasar hukum yang tepat terhadap rencana pengembangan HHBK di daerah;

${ }^{4}$ Dephut, 2009.

${ }^{5}$ WWF, 2012. 
(2). Menelaah respon stakeholders di daerah terhadap rencana pengembangan HHBK;

(3). Merumuskan rekomendasi tindak lanjut rencana pengembangan HHBK di daerah.

Lokasi kajian dilakukan di dua propinsi yakni Propinsi Nusa Tenggara Barat (NTB) dan Propinsi Nusa Tenggara Timur (NTT). Di NTB lokasi kajian terfokus padadua Kabupaten yakni Kabupaten Lombok Utara dan Kabupaten Lombok Tengah. Di NTT, lokasi kajian terletak di Kabupaten Timur Tengah Selatan (TTS).

\section{Metode Penelitian}

Metode kajian dilakukan dengan menggabungkan metode penelitian hukum normatif maupun empiris. Metode penelitian hukum yang bersifat empiris dimaksudkan untuk menggambarkan bagaimana hukum normatif berlaku atau dilaksanakan di dalam masyarakat. ${ }^{6}$ Kajian hukum dari aspek normatif dalam penelitian ini dilakukan dengan cara menganalisis peraturan perundang-undangan mulai dari kebijakan tingkat pusat sampai kebijakan di tingkat kabupaten yang terkait dengan isu pengembangan HHBK.

Kajian hukum empiris dalam penelitian ini dilakukan secara Modified Participatory Action Research. Artinya, penelitian dilakukan dengan melibatkan partisipasi stakeholders dalam proses kajian. Metodenya dengan mengkombinasikan analisis data sekunder dengan data yang dikumpulkan melalui in-depth interview dan Focus Group Discussion (FGD). ${ }^{7}$ Pendekatan Modified Participatory Action Research dimaksudkan untuk mengetahui fakta di lapangan (existing condition) berupa kondisi sosial dan kondisi lingkungan, respon para pihak dan untuk memperoleh input dan gagasan terkait dengan rencana perumusan kebijakan HHBK

Adapun rencana kerja dalam penelitian ini, dilakukan secara bertahap yakni: pengumpulan bahan hukum, kajian berbagai produk perundangundangan yang terkait, pelaksanaan in-depth interview, Focus Group Discussion di tiga lokasi penelitian (Kabupaten Lombok Utara, Kabupaten Lombok Tengah di NTB dan Kabupaten Timur Tengah Selatan (NTT); penyusunan draft laporan; workshop dan penyusunan laporan akhir penelitian.

${ }^{6}$ Soerjono Soekanto dan Sri Mamudji, 2000.

${ }^{7}$ Muktasam, 2008. 


\section{Hasil Penelitian Dan Pembahasan}

\section{a. AnalisisProduk Kebijakan}

Analisis kebijakan HHBK dilakukan melalui dua cara. Pertama indentifikasi produk-produk kebijakan yang terkait dengan pengelolaan HHBK mulai dari produk kebijakan paling tinggi (Undang-undang Dasar) sampai produk kebijakan pada tingkat kabupaten. Kedua hasil identifikasi kemudian dianalisis lebih lanjut untuk menemukan pijakan hukum dalam merumuskan pilihan kebijakan dalam bentuk usulan kebijakan di tingkat daerah maupun pilihan kebijakan pada tingkat pusat.

Hasil identifikasi produk kebijakan dalam laporan ini memuat tentang produk kebijakan dan substansi materi yang dapat dijadikan pijakan hukum dalam merumuskan pilihan kebijakan. Hasil identifikasi yang dimaksud disajikan pada tabel berikut.

Tabel 1. Hirarki produk kebijakan yang terkait dengan pengelolaan HHBK

\begin{tabular}{|l|l|l|}
\hline No & \multicolumn{1}{|c|}{ Produk Kebijakan } & \multicolumn{1}{c|}{ Materi } \\
\hline 1. & $\begin{array}{l}\text { Undang-Undang Dasar } \\
1945\end{array}$ & $\begin{array}{l}\text { HHBK merupakan bagian dari kekayaan alam } \\
\text { Indonesia yang harus dpergunakan untuk } \\
\text { sebesar-besarnya "kemakmuran rakyat". } \\
\text { - }\end{array}$ \\
\hline 2egara memiliki hak untuk menguasai dan \\
selanjutnya mengatur peruntukannya agar \\
sesuai dengan peraturan perundang-undangan \\
yang berlaku
\end{tabular}




\begin{tabular}{|c|c|c|}
\hline No & Produk Kebijakan & Materi \\
\hline & & $\begin{array}{l}\text { untuk manusia. } \\
\text { - Konsep yang ingin dikembangkan adalah } \\
\text { "hutan lestari masyarakat sejahtera" }\end{array}$ \\
\hline 4. & $\begin{array}{l}\text { Undang-Undang Nomor } \\
32 \text { Tahun } 2004 \text { tentang } \\
\text { Pemerintahan Daerah }\end{array}$ & $\begin{array}{l}\text { - Menjadi landasan yuridis dalam kaitannya } \\
\text { kewenangan pemanfaatan sumber daya alam } \\
\text { termasuk HHBK antara Pemerintah dan } \\
\text { pemerintahan daerah, maupun antar } \\
\text { pemerintahan daerah } \\
\text { - Menjadi dasar hukum dalam melakukan kerja } \\
\text { sama dan bagi hasil atas pemanfaatan sumber } \\
\text { daya alam termasuk HHBK. Dan sumber daya } \\
\text { lainnya antar pemerintahan daerah; dan } \\
\text { - Oleh karena kewenangan yang dimiliki } \\
\text { berdasarkan peraturan perundang-undangan } \\
\text { (atributif), Pemerintah dan Pemerintah daerah } \\
\text { memiliki wewenang menerbitkan perizinan } \\
\text { dalam pemanfaatan sumber daya alam } \\
\text { termasuk (HHBK) dan sumber daya lainnya. }\end{array}$ \\
\hline 5. & $\begin{array}{l}\text { Peraturan Pemerintah } \\
\text { Nomor } 38 \text { Tahun } 2007 \\
\text { tentang Pembagian } \\
\text { Urusan Pemerintah, } \\
\text { Pemerintah Provinsi dan } \\
\text { Pemerintah } \\
\text { Kabupaten/Kota }\end{array}$ & $\begin{array}{l}\text { - Melaksanakan ketentuan Pasal } 14 \text { ayat (3) } \\
\text { Undang-Undang Nomor } 32 \text { Tahun } 2004 \\
\text { tentang Pemerintahan Daerah, yang pada } \\
\text { intinya mengatur pembagian urusan } \\
\text { pemerintahan antara pemerintah, pemerintah } \\
\text { propinsi dan pemerintah kabupaten/kota } \\
\text { - Pemerintah daerah menjalankan otonomi } \\
\text { seluas-luasnya untuk mengatur dan mengurus } \\
\text { sendiri urusan pemerintahan berdasarkan asas } \\
\text { otonomi dan tugas pembantuan } \\
\text { - Urusan pemerintahan yang menjadi } \\
\text { kewenangan pemerintah } \\
\text { diselenggarakan berdasarkan kriteria } \\
\text { eksternalitas, akuntabilitas, dan efisiensi serta } \\
\text { terdiri atas urusan wajib dan urusan pilihan } \\
\text { - Urusan pilihan, baik pemerintah propinsi } \\
\text { maupun kabupaten kota meliputi urusan } \\
\text { pemerintahan yang secara nyata ada, dan } \\
\text { berpotensi kebiasaan dan potensi unggulan } \\
\text { daerah yang bersangkutan. } \\
\text { Urusan kehutanan termasuk HHBK adalah } \\
\text { urusan wajib dan pilihan yang harus } \\
\text { dilaksanakan dengan sebaik-baiknya }\end{array}$ \\
\hline 6. & $\begin{array}{l}\text { Peraturan Pemerintah } \\
\text { Nomor } 6 \text { Tahun } 2007 \\
\text { tentang Tata Hutan dan } \\
\text { Penyusunan Rencana }\end{array}$ & $\begin{array}{l}\text { - Pemanfaatan hasil hutan bukan kayu adalah } \\
\text { kegiatan untuk memanfaatkan dan } \\
\text { mengusahakan hasil hutan berupa bukan kayu }\end{array}$ \\
\hline
\end{tabular}




\begin{tabular}{|c|c|c|}
\hline No & Produk Kebijakan & Materi \\
\hline & $\begin{array}{l}\text { Pengelolaan Hutan, serta } \\
\text { Pemanfaatan Hutan }\end{array}$ & $\begin{array}{l}\text { dengan tidak merusak lingkungan dan tidak } \\
\text { mengurangi fungsi pokoknya (Pasal } 1 \text { angka } \\
\text { 8). } \\
\text { - Pemungutan hasil hutan kayu dan/atau bukan } \\
\text { kayu adalah kegiatan untuk mengambil hasil } \\
\text { hutan baik berupa kayu dan/atau bukan kayu } \\
\text { dengan batasan waktu, luas dan/atau volume } \\
\text { tertentu.(Pasal } 1 \text { angka 9) } \\
\text { - Izin usaha pemanfaatan hasil hutan kayu yang } \\
\text { selanjutnya disingkat IUPHHK dan/atau izin } \\
\text { usaha pemanfaatan hasil hutan bukan kayu } \\
\text { yang selanjutnya disebut IUPHHBK adalah } \\
\text { izin usaha yang diberikan untuk memanfaatkan } \\
\text { hasil hutan berupa kayu dan/atau bukan kayu } \\
\text { dalam hutan alam pada hutan produksi melalui } \\
\text { kegiatan pemanenan atau penebangan, } \\
\text { pengayaan, pemeliharaan dan pemasaran } \\
\text { (Pasal } 1 \text { angka } 13 \text { ) } \\
\text { IUPHHK dan/atau IUPHHBK dalam hutan } \\
\text { tanaman adalah izin usaha yang diberikan } \\
\text { untuk memanfaatkan hasil hutan berupa kayu } \\
\text { dan/atau bukan kayu dalam hutan tanaman } \\
\text { pada hutan produksi melalui kegiatan } \\
\text { penyiapan lahan, pembibitan, penanaman, } \\
\text { pemeliharaan, pemanenan, dan pemasaran } \\
\text { (Pasal } 1 \text { angka } 15 \text { ). } \\
\text { Izin pemungutan hasil hutan kayu yang } \\
\text { selanjutnya disingkat IPHHK adalah izin untuk } \\
\text { mengambil hasil hutan berupa kayu pada hutan } \\
\text { produksi melalui kegiatan pemanenan, } \\
\text { pengangkutan, dan pemasaran untuk jangka } \\
\text { waktu dan volume tertentu(Pasal } 1 \text { angka } 16 \text { ). } \\
\text { Izin pemungutan hasil hutan bukan kayu yang } \\
\text { selanjutnya disingkat IPHHBK adalah izin } \\
\text { untuk mengambil hasil hutan berupa bukan } \\
\text { kayu pada hutan lindung dan/atau hutan } \\
\text { produksi antara lain berupa rotan, madu, buah- } \\
\text { buahan, getah-getahan, tanaman obat-obatan, } \\
\text { untuk jangka waktu dan volume tertentu (Pasal } \\
1 \text { angka 17). }\end{array}$ \\
\hline 7. & $\begin{array}{l}\text { Peraturan Menteri } \\
\text { Kehutanan Nomor : P.35 / } \\
\text { Menhut-II/2007 tentang } \\
\text { Hasil Hutan Bukan Kayu }\end{array}$ & $\begin{array}{l}\text { - HHBK yang berasal dari hutan tunduk dan } \\
\text { diatur sesuai ketentuan di bidang kehutanan. } \\
\text { - HHBK yang tidak tercantum dalam lampiran } \\
\text { peraturan ini sepanjang berasal dari hutan, } \\
\text { tunduk dan diatur sesuai ketentuan di bidang } \\
\text { kehutanan. }\end{array}$ \\
\hline
\end{tabular}




\begin{tabular}{|c|c|c|}
\hline No & Produk Kebijakan & Materi \\
\hline & & $\begin{array}{l}\text { - HHBK sebagaimana tercantum dalam lampiran } \\
\text { peraturan ini sepanjang berasal dari luar hutan, } \\
\text { tunduk dan diatur sesuai ketentuan yang } \\
\text { berlaku. } \\
\text { - HHBK yang berupa tumbuhan dan satwa liar } \\
\text { yang dilindungi dan tidak dilindungi serta yang } \\
\text { termasuk dalam daftar Appendix Cites, tunduk } \\
\text { dan diatur sesuai ketentuan yang berlaku }\end{array}$ \\
\hline 8. & $\begin{array}{l}\text { Peraturan Menteri } \\
\text { Kehutanan Republik } \\
\text { Indonesia Nomor } \\
\text { P.19/Menhut-Ii/2009 } \\
\text { Strategi Pengembangan } \\
\text { Hasil Hutan Bukan Kayu } \\
\text { Nasional }\end{array}$ & $\begin{array}{l}\text { - Penyusunan Grand Strategy ini adalah untuk } \\
\text { memberikan arah, kebijakan serta gambaran } \\
\text { pengembangan HHBK kepada pelaku usaha, } \\
\text { para pihak dan masyarakat yang akan } \\
\text { mengembangkan usaha HHBK. Sedangkan } \\
\text { tujuannya adalah : } \\
\text { - Menggali potensi daerah dalam pengembangan } \\
\text { HHBK sebagai alternatif sumber pangan, } \\
\text { sumber bahan obat-obatan, penghasil serat, } \\
\text { penghasil getah-getahan dan lainnya yang } \\
\text { dapat meningkatkan kesejahteraan masyarakat. } \\
\text { - Mendukung kebijakan nasional dalam } \\
\text { mengembangkan dan meningkatkan produksi } \\
\text { HHBK. } \\
\text { Adanya acuan mulai dari perencanaan sampai } \\
\text { pasca panen bagi pelaku usaha, para pihak dan } \\
\text { masyarakat luas dalam pengembangan HHBK }\end{array}$ \\
\hline 9. & $\begin{array}{l}\text { Peraturan Menteri } \\
\text { Kehutanan Republik } \\
\text { Indonesia Nomor : P. } \\
\text { 21/Menhut-Ii/2009 } \\
\text { tentang Kriteria Dan } \\
\text { Indikator Penetapan Jenis } \\
\text { Hasil Hutan Bukan Kayu } \\
\text { Unggulan }\end{array}$ & $\begin{array}{l}\text { - Penyusunan kriteria dan standar ini } \\
\text { dimaksudkan sebagai acuan dalam penetapan } \\
\text { jenis HHBK unggulan serta menyamakan } \\
\text { pemahaman dan langkah dalam upaya } \\
\text { pengembangan HHBK untuk meningkatkan } \\
\text { kesejahteraan masyarakat. } \\
\text { - Sedangkan tujuannya adalah tersedianya jenis- } \\
\text { jenis HHBK unggulan yang akan } \\
\text { dikembangkan secara lebih terfokus dan } \\
\text { terarah menjadi komoditas yang mempunyai } \\
\text { nilai ekonomi tinggi baik di tingkat nasional } \\
\text { maupun daerah }\end{array}$ \\
\hline 10. & $\begin{array}{l}\text { Peraturan Menteri } \\
\text { Kehutanan Republik } \\
\text { Indonesia Nomor : P. } \\
\text { 46/Menhut-Ii/2009 } \\
\text { tentang Tata Cara } \\
\text { Pemberian Izin } \\
\text { Pemungutan Hasil Hutan } \\
\text { Kayu Atau Hasil Hutan }\end{array}$ & $\begin{array}{l}\text { - Izin Pemungutan Hasil Hutan Kayu yang } \\
\text { selanjutnya disingkat IPHHK adalah } \\
\text { sebagaimana tercantum dalam Pasal } 1 \text { angka } \\
\text { 16 Peraturan Pemerintah Nomor } 6 \text { Tahun } 2007 \\
\text { jo. Peraturan Pemerintah Nomor } 3 \text { Tahun } \\
\text { 2008. } \\
\text { - Izin Pemungutan Hasil Hutan Bukan Kayu } \\
\text { yang selanjutnya disingkat IPHHBK adalah }\end{array}$ \\
\hline
\end{tabular}




\begin{tabular}{|c|c|c|}
\hline No & Produk Kebijakan & Materi \\
\hline & $\begin{array}{l}\text { Bukan Kayu Pada Hutan } \\
\text { Produksi }\end{array}$ & $\begin{array}{l}\text { sebagaimana tercantum dalam Pasal } 1 \text { angka } \\
17 \text { Peraturan Pemerintah Nomor } 6 \text { Tahun } 2007 \\
\text { jo. Peraturan Pemerintah Nomor } 3 \text { Tahun } \\
\text { 2008. }\end{array}$ \\
\hline 11. & $\begin{array}{l}\text { Peraturan Menteri } \\
\text { Kehutanan Republik } \\
\text { Indonesia Nomor : } \\
\text { P.8/Menhut-II/2010 } \\
\text { tentang Rencana Strategis } \\
\text { (Renstra Kementerian } \\
\text { Kehutanan Tahun } 2010 \text { - } \\
2014\end{array}$ & $\begin{array}{l}\text { - Dalam bab mengenai Pemberdayaan Ekonomi } \\
\text { Masyarakat di Dalam dan Sekitar Kawasan } \\
\text { Hutan ditegaskan, bahwa: } \\
\text { " Kegiatan yang dilakukan untuk } \\
\text { mendukung kebijakan prioritas } \\
\text { Pemberdayaan Ekonomi Masyarakat Di } \\
\text { Dalam dan Sekitar Kawasan Hutan, } \\
\text { dilakukan melalui kegiatan pengembangan } \\
\text { dan pemberdayaan perekonomian } \\
\text { masyarakat melalui pengembangan hutan } \\
\text { kemasyarakatan, hutan rakyat, hutan desa, } \\
\text { dan pengembangan desa konservasi. } \\
\text { Selanjutnya peningkatan usaha } \\
\text { perekonomian masyarakat dilakukan } \\
\text { melalui pengembangan komoditas } \\
\text { kehutanan berupa kayu dan non kayu/hasil } \\
\text { hutan bukan kayu (HHBK) seperti rotan, } \\
\text { getah-getahan, buah-buahan, umbi-umbian, } \\
\text { serta usaha jasa pariwisata alam”. }\end{array}$ \\
\hline 12. & $\begin{array}{l}\text { Peraturan Daerah Provinsi } \\
\text { Nusa Tenggara Barat No. } \\
6 \text { Tahun } 2004 \text { tentang } \\
\text { Pedoman } \\
\text { Penyelenggaraan Hutan } \\
\text { Kemasyarakatan (HKm) } \\
\text { Di Provinsi Nusa } \\
\text { Tenggara Barat }\end{array}$ & $\begin{array}{l}\text { - Peraturan Daerah ini secara substansial } \\
\text { pembentukannya didasarkan kepada Undang- } \\
\text { Undang Nomor 41 Tahun } 1999 \text { tentang } \\
\text { Kehutanan dan Peraturan Pemerintah Nomor } \\
34 \text { Tahun } 2002 \text { tentang Tata Hutan dan } \\
\text { Penyusunan Rencana Pengelolaan Hutan, } \\
\text { Pemanfaatan Hutan dan Penggunaan Kawasan } \\
\text { Hutan. } \\
\text { - Penormaan di dalam Peraturan Daerah ini } \\
\text { banyak mengulangi norma-norma yang diatur } \\
\text { di dalam UU No. 41 Tahun 1999 dan PP } 34 \\
\text { Tahun 2002 ( terjadi repetisi norma) yang } \\
\text { sebenarnya tidak harus dilakukan karena akan } \\
\text { mengurangi norma yang diatur di dalam } \\
\text { peraturan yang sudah mengaturnya ( UU dan } \\
\text { PP). tidak secara } \\
\text { Peraturan Daerah ini Huan } \\
\text { terperincimengatur tentang Hasil Hutan Bukan } \\
\text { Kayu (HHBK) }\end{array}$ \\
\hline 13. & $\begin{array}{l}\text { Peraturan Daerah } \\
\text { Kabupaten Lombok } \\
\text { Tengah Nomor } 4 \text { Tahun } \\
2009 \text { tentang }\end{array}$ & $\begin{array}{l}\text { - Merujuk pada ketentuan Pasal } 96 \text { Peraturan } \\
\text { Pemerintah Nomor } 6 \text { Tahun } 2007 \text { tentang Tata } \\
\text { Hutan dan Penyusunan Rencana Pengelolan }\end{array}$ \\
\hline
\end{tabular}




\begin{tabular}{|c|c|c|}
\hline No & Produk Kebijakan & Materi \\
\hline & $\begin{array}{l}\text { Penyelenggaraan Hutan } \\
\text { Kemasyarakatan (HKm) }\end{array}$ & $\begin{array}{l}\text { Hutan serta Pemanfaatan Hutan. } \\
\text { - Tujuan penyelenggaraan } \\
\text { kemasyarakatan adalah untuk menngkatkan } \\
\text { kesejahteraan masyarakat setempat melalui } \\
\text { pemanfaatan sumber daya hutan secara } \\
\text { optimal. Adil dan berkelanjutan dengan tetap } \\
\text { menjaga kelestarian hutan dan lingkungan } \\
\text { hidup } \\
\text { - Mengatur jenis-jenis perizinan usaha } \\
\text { pemanfaatan } \\
\text { - hutan kemasyarakatan, Izin Usaha } \\
\text { Pemanfaatan Hasil Kayu dalam HKm dan Izin } \\
\text { Usaha Pemanfaatan Hasil Hutan Bukan Kayu } \\
\text { dalam HKm. }\end{array}$ \\
\hline 14. & $\begin{array}{l}\text { Rencana Pengembangan } \\
\text { Jangka Menengah } \\
\text { (RPJM) Lombok Tengah } \\
\text { Tahun } 2011-2015\end{array}$ & $\begin{array}{l}\text { - Dalam arah dan stategi pengembangan daerah, } \\
\text { tidak secara eksplisit mengatur mengenai arti } \\
\text { pentingnya HHBK sebagai potensi unggulan } \\
\text { daerah yang layak untuk dikembangkan, } \\
\text { padahal daerah ini memiliki kawasan hutan } \\
\text { (HHBK) yang sangat potensial untuk } \\
\text { dikembangkan untuk meningkatkan } \\
\text { kesejahteraan masyarakat. }\end{array}$ \\
\hline 15. & $\begin{array}{l}\text { Rencana Pengembangan } \\
\text { Jangka Menengah } \\
\text { (RPJM) Lombok Tengah } \\
\text { Tahun } 2011-2015\end{array}$ & $\begin{array}{l}\text { - Tidak jauh berbeda dengan kondisi faktual di } \\
\text { Lombok Tengah, di Kabupaten Lombok Utara } \\
\text { pun dalam RPJMD nya tidak mengatur secara } \\
\text { eksplisit rencana pengembangan HHBK } \\
\text { sebagai potensi unggulan daerah }\end{array}$ \\
\hline
\end{tabular}

Secara yuridis normatif, hukum dapat dimaknai sebagai peraturan perundang-undangan. Sedangkan dalam sistem peraturan perundangundangan sendiri ada berbagai asas perundang-undangan yang harus dipatuhi, antara lain peraturan perundang-undangan yang lebih rendah tidak boleh bertentangan dengan peraturan perundang-undangan yang lebih tinggi. Tegasnya, ada hirarkhi tata urutan peraturan perundangundanganyang harus diperhatikan berikut materi muatan yang diaturnya. Dalam konteks pengelolaan HHBK ada berbagai produk kebijakan yang relevan untuk dapat dijadikan sebagai rujukan pengaturan, mulai dari norma yang paling tinggi (konstitusi) sampaikepada norma yang paling rendah (Peraturan daerah).

Undang-Undang Dasar 1945 secara implisit menegaskan bahwa kekayaan alam Indonesia (termasuk HHBK) harus dpergunakan untuk sebesar-besar "kemakmuran rakyat". Negara memiliki hak untuk menguasai dan selanjutnya mengatur peruntukannya agar sesuai dengan peraturan perundang-undangan yag berlaku. 
Peraturan yang berskala nasional (mulai dari undang-undang, peraturan pemerintah sampai pada peraturan menteri kehutanan) sebagai dasar rujukan HHBK sudah cukup memadai. Artinya, hal-hal yang bersifat umum dan makro dari ketentuan undang-undang telah dijabarkan secara teknis kedalam peraturan yang lebih rendah baik dalam bentuk peraturan pemerintah maupun peraturan menteri kehutanan.

Undang-Undang Nomor 5 Tahun 1990 tentang konservasi sumberdaya alam hayati dan ekosistemnya jelas mengedepankan "konservasi", oleh karena itu keberadaan HHBK harus dipandang sebagai upaya perlindungan terhadap konservasi sumberdaya alam hayati dan ekosistemnya. Hal ini bisa dimengerti karena undang-undang ini menganut konsep "ekosentris" artinya, tujuan dari perlindungan lingkungan pada dasarnya adalah lingkungannya itu sendiri.

Berbeda dengan Undang-Undang Nomor 5 Tahun 1990, Undang Undang Nomor 41 Tahun 1999 tentang Kehutanan, nampaknya menganut konsep "anthroposentris", bahwa lingkungan (hutan) untuk manusia. Konsep yang ingin dikembangkan adalah "hutan lestari masyarakat sejahtera”. Jadi, disamping mempertimbangkan aspek konservasi hutan, undang-undang ini juga memberi peluang untuk memanfaatkan hutan secara ekonomis. HHBK memiliki potensi ekonomi tinggi sekaligus dapat meningkatkan kesejahteraan masyarakat

Disamping, kedua undang undang tersebut, juga telah diterbitkan Peraturan Menteri Kehutanan Nomor: P.37/Menhut-II/2007Tentang Hutan Kemasyarakatan. Artinya, ada kesadaran dari pengambil kebijakan bahwa untuk mengelola hutan tidak bisa dibebankan kepada Pemerintah semata, melainkan juga perlu melibatkan masyarakat khususnya masyarakat di kawasan hutan.

Penting untuk dicermati, produk kebijakan yang lahir yang mengatur masalah hutan telah mencerminkan apa yang menjadi isu sentral pada KTT Bumi di Rio de Janeiro Brasil, yang melahirkan konsep "pembangunan berkelanjutan" (sustainable development). Pembangunan berkelanjutan mensyaratkan adanya tiga elemen penting yang harus dipenuhi, yakni keberlanjutan secara ekologi, keberlanjutan secara ekonomi dan keberlanjutan secara sosial.

Secara konseptual, pembangunan berkelanjutan khususnya di bidang kehutanan sangat baik. Instrumen yuridis pendukung mulai dari tataran undang-undang, peraturan pemerintah sampai peraturan menteri kehutanan cukup memadai. Akan tetapi acapkali dalam implementasi, aturan-aturan tersebut tidak bisa dilaksanakan dengan baik. Nampaknya ada kegamangan pada pengampu kebijakan level lokal di daerah untuk menindaklanjuti dan mengambil keputusan yang strategis berkaitan dengan HHBK. Analisis sementara menunjukkan bahwa kebijakan yang bersifat nasional baik dalam bentuk undang-undang, peraturan pemerintah, peraturan menteri kehutanan, tidak ditindaklanjuti dalam kebijakan lokal. Peraturan Daerah Propinsi, Peraturan Daerah Kabupaten maupun produk kebijakan lainnya, seperti Rencana Pengembangan 
Daerah (RPJM) tidak secara tegas dan terperinci mengatur tentang HHBK.

Disisi lain, ada kesenjangan antara apa yang seharusnya (das sollen) dengan apa yang senyatanya (das sein). Contoh kesenjangan antara das sollen dan das sein khususnya di bidang kehutanan, misalnya terlihat pada Peraturan Menteri Nomor P.35/ Menhut-II/2007 tentang Hasil Hutan Bukan Kayu berikut lampiran komoditi yang telah ditentukan secara limitatif. Dalam praktek - sekurang-kurangnya yang terjadi di daerah penelitian - banyak sekali komoditi yang dikembangkan oleh masyarakat lokal yang tidak ditetapkan sebagai bagian dari lampiran Peraturan Menteri Kehutanan Nomor P.35/Menhut-II/2007.

Masyarakat lokal mengembangkan komoditi diluar apa yang sudah ditetapkan dalam Peraturan Menteri Kehutanan Nomor 35 Tahun 2007 tersebut. Tidak hanya fakta tersebut yang ditemukan di lapangan, dalam penelitian ini hadir pula temuan lain yang memperlihatkan bahwa perlu langkah-langkah strategis yang harus dilakukan untuk meningkatkan kesejahteraan masyarakat di dalam kawasan hutan dengan tetap menjaga dan mempertahankan fungsi pokok hutan. Disisi lain, dalam Peraturan Menteri Kehutanan Nomor P.35/Menhut-II/2007 ditegaskan bahwa:

(1).HHBK yang berasal dari hutan tunduk dan diatur sesuai ketentuan di bidang kehutanan.

(2).HHBK yang tidak tercantum dalam lampiran peraturan ini sepanjang berasal dari hutan, tunduk dan diatur sesuai ketentuan di bidang kehutanan.

(3). HHBK sebagaimana tercantum dalam lampiran peraturan ini sepanjang berasal dari luar hutan, tunduk dan diatur sesuai ketentuan yang berlaku.

(4). HHBK yang berupa tumbuhan dan satwa yang dilindungi dan tidak dilindungi serta yang termasuk dalam daftar Appendix Cites, tunduk dan diatur sesuai ketentuan yang berlaku.

Kendatipun di tingkat Pusat, telah ada pengaturan yang secara limitatif mengenai HHBK, namun di tingkat daerah (sekurang-kurangnya pada tiga lokasi penelitian), belum ada pengaturan yang secara khusus mengatur mengenai HHBK ini. Derivasi atau turunan dari norma yang lebih tinggi dapat dijadikan sebagai acuan atau pedoman untuk pengaturan HHBK di tingkat daerah.

\section{b. Analisis Sosial (Empiris)}

\section{a. Kabupaten Lombok Utara (KLU)}

Berdasarkan dokumen hasil penelitian Rencana Pengelolaan HHBK di KLU tentang potensi HHBK yang berada di dalam kawasan hutan maupun di luar kawasan hutan yang dilakukan oleh WWF Nusa Tenggara (2012) menyebutkan bahwa, potensi HHBK di dalam kawasan hutan yakni di dalam kawasan HKm sebanyak 27 
komoditi dan di luar HKm sebanyak 19 komoditi. Sedangkan potensi HHBK di luar kawasan hutan sebanyak 25 komoditi. Adapun jumlah komoditi tersebut dimungkinkan bertambah. Kemungkinan pertambahan komoditi tersebut terjadi mengingat sampai saat ini belum dilakukan identifikasi dan pemetaan secara lengkap terhadap jumlah komoditi HHBK. Sebagai contoh, di KLU terdapat komoditas unggulan seperti Mangga Bayan, dan Kemiri. Tetapi selama ini pengelolaannya kurang mendapat dukungan dari pemerintah daerah setempat.

Mengingat potensi HHBK baik dalam kawasan hutan maupun di luar kawasan hutan cukup besar, maka pemerintah daerah perlu memberikan pengaturan yang dapat memberikan kemudahan dan keuntungan ekonomi kepada masyarakat terutama yang tinggal di sekitar kawasan hutan. Pengaturan tersebut merupakan wujud keberpihakan pemerintah dalam mengurangi jumlah masyarakat miskin di sekitar kawasan hutan yang sampai saat ini masih cukup besar. Selain itu, pengaturan HHBK dapat memberikan jaminan dan legitimasi dalam memanfaatkan sumberdaya alam. Hal itu sesuai dengan fakta di lapangan, dimana sumber penghidupan masyarakat dominan bergantung pada HHBK.

Dalam konteks, perumusan peraturan pengelolaan HHBK harus tetap merujuk pada peraturan yang ada.Sebagai langkah awal, dapat dirumuskan kebijakan pada tingkat lokal, yang sesuai dengan kesiapan daerah KLU berupa Kelompok Kerja (POKJA). Peran dan fungsi POKJA ini adalah untuk dapat mengakselerasi perumusan kebijakan berupa penentuan komoditas unggulan dan Peraturan Daerah (PERDA).

Beberapa hal yang penting untuk dijadikanfokus penelaahan dalam rangka mempersiapkan peraturan meliputi:

a. Kejelasan mekanisme koordinasi dan pembagian peran antar instansi vertikal dengan SKPD di daerah;

b. Strategi implementasi pengelolaan HHBK;

c. Penyiapan kelembagaan masyarakat;

d. Infrastruktur pemasaran;

e. Karakteristik dan nilai-nilai kearifan lokal.

Dalam merumuskan pengaturan pengelolaan HHBK, penting untuk memperhatikan Peraturan Menteri Kehutanan Nomor: P.35/Menhut-II/2007 tentang Hasil Hutan Bukan Kayu. Klausul yang harus diperhatikan menyangkut:

a. HHBK yang berasal dari hutan tunduk dan diatur sesuai ketentuan di bidang kehutanan;

b. HHBK yang tidak tercantum dalam lampiran peraturan ini sepanjang berasal dari hutan, tunduk dan diatur sesuai ketentuan di bidang kehutanan; dan 
c. HHBK sebagaimana tercantum dalam lampiran peraturan ini sepanjang berasal dari luar hutan, tunduk dan diatur sesuai ketentuan yang berlaku.

Dalam kontek KLU, sementara ini terdapat 25 komoditi yang berada di luar kawasan hutan. Oleh karena itu dalam menyusun peraturan harus mampu merumuskan sinkronisasi kebijakan yang tepat agar tidak kontra produktif.

Berdasarkan hasil kajian, ditemukan sejumlah permasalahan sebagai berikut:

a. Secara kelembagaan, pengelolaan kehutanan masih digabungkan dengan bidang yang lain seperti pertanian, perkebunan dan peternakan. Hal itu berimplikasi pada terbatasnya ruang lingkup dalam aspek perencanaan dan alokasi pendanaan.

b. Berdasarkan Permenhut No.: P. 35/Menhut-II/2007 tentang HHBK, diketahui bahwa peraturan tersebut - khususnya bagian pengaturan tentang komoditas - belum mengakomodir sejumlah komoditas yang banyak diusahakan oleh masyarakat. Perlu dicari solusi untuk menjamin kepastian hukum terhadap komoditas yang sudah ada. Dalam mencari solusi tersebut diperlukan adanya pertimbangan dan kehati-hatian mengingat komoditas yang dominan ditanami masyarakat merupakan komoditas perkebunan yang selama ini cukup resisten dengan institusi kehutanan. Untuk itu, penentuan komoditas HHBK harus tetap mempertahankan karakteristik fisik, nilai dan fungsi hutan.

c. Bahwa HHBK sampai saat ini belum sepenuhnya menjadi kepedulian (concern) meski disadari bahwa potensi HHBK cukup tinggi serta memberikan kemanfaatan sebesar-besar bagi rakyat khususnya di sekitar kawasan hutan. Indikasi ini terlihat bahwa kebijakan HHBK belum dituangkan dalam produk legislasi atau rencana strategis di KLU.

d. Belum ada kejelasan bentuk hukum (produk kebijakan) yang tepat dalam pengelolaan HHBK di daerah.

Terlepas dari sejumlah permasalahan di atas, respon stakeholders (pemerintah daerah, LSM, perguruan tinggi dan masyarakat) terhadap upaya untuk mendorong kebijakan pengelolaan HHBK cukup mendukung. Selain itu rencana penyusunan kebijakan HHBK sudah ada dukungan secara akademik dan teknis. Meski demikian, disadari ke depan perlu adanya dorongan kepada para stakeholder untukmemberikan dukungan secara politis kepada kebijakan pengelolaan HHBK. 
Pentingnya regulasi pengelolaan HHBK diharapkan dapat menjadi payung hukum dan jaminan bagi masyarakat dalam mengelola HHBK. Bagi pemerintah daerah terutama instansi teknis, regulasi pengelolaan HHBK diharapkan dapat menjadi rujukan dalam menyusun program untuk mendukung pengelolaan tersebut. Oleh karena itu diperlukan langkah-langkah strategis meliputi:

a. Perlunya pembentukan POKJA yang bertugas untuk mempersiapkan dan mempercepat rencana pengelolaan HHBK. Payung hukum pembentukan POKJA dilakukan melalui keputusan Bupati.;

b. Perlunya mempercepat penetapan produk HHBK unggulan daerah. Penetapan produk tersebut menjadi salah satu peran POKJA;

c. Perlunya penetapan manajemenplan pengelolaan HHBK yang nantinya menjadi acuan diantara instansi teknis;

d. Perlunya produk kebijakan pengelolaan HHBK yang didalamnya memuat:

- Mekanisme pemberian insentif dan disinsentif;

- Perijinan dan tata niaga HHBK;

- Penerapan tekhnologi yang ramah lingkungan;

- Mekanisme koordinasi dan pembagian peran kelembagaan daerah dan instansi vertikal yang ada di daerah;

- Penguatan kelembagaan masyarakat;

- Pengaturan jaringan pemasaran produk HHBK.

\section{b. Kabupaten Lombok Tengah}

Berdasarkan dokumen hasil penelitian rencana pengelolaan HHBK di Kabupaten Lombok Tengah tentang potensi HHBK yang berada di dalam kawasan hutan maupun di luar kawasan hutan yang dilakukan oleh WWF Nusa Tenggara (2012) menyebutkan bahwa, potensi di dalam kawasan HKm sebanyak 39 komoditi dan di luar HKm sebanyak 23 komoditi. Potensi HHBK di luar kawasan hutan sebanyak 36 komoditi.Adapun jumlah komoditi tersebut dimungkinkan bertambah, karena sampai saat ini belum ada dokumen hasil identifikasi dan pemetaan secara lengkap jumlah komoditi HHBK. Hal itu mengingat potensi pengembangan HHBK di dalam kawasan hutan mencapai sekitar 8.000 ha.

Terhadap rencana penyusunan regulasi pengelolaan HHBK, stakeholders (mencakup pihak eksekutif, legislatif, LSM lokal dan masyarakat) memberikan persetujuan untuk mendukung inisiatif pengaturan kebijakan tentang HHBK. Persetujuan tersebut diberikan mengingat potensi ekonomi yang mendukung dan manfaat ekologi bagi kawasan hutan. 
Berdasarkan hasil kajian, inisiatif perumusan kebijakan pengelolaan HHBK dapat menjadi aturan tersendiri atau disinkronkan dengan kebijakan Rencana Pengembangan Agrobisnis Turisme dan Kelautan yang saat ini masih dalam proses perumusan. Melalui pengaturan HHBK dapat memberikan jaminan dan legitimasi bagi masyarakat dalam memanfaatkan sumberdaya alam. Fakta di lapangan, masyarakat menggantungkan hidupnya dari HHBK terutama di wilayah Hutan Kemasyarakatan $(\mathrm{HKm})$ di wilayah Batu Kliang Utara maupun di wilayah bagian selatan.

Berdasarkan hasil kajian, jika pengelolaan HHBK menjadi peraturan tersendiri, maka penting memperhatikan beberapa hal yakni:

a. Sebelum merumuskan rencana pengelolaan HHBK menjadi kebijakan daerah harus didahului oleh kajian yang komprehensif yang memuat kajian aspek sosial, ekonomi, pemetaan potensi dan strategi implementasi;

b. Rumusan pengaturan pengelolaan HHBK harus tegas merumuskanhak dan kewajiban pemerintah dan masyarakat. Masyarakat harus memperoleh manfaat dan ditegaskan perannya dalam konservasi agar luaskerusakan hutan dapat dikurangi.Pemerintah harus memberikan pembinaan termasuk dukungan penganggaran;

c. Kejelasan mekanisme koordinasi dan pembagian peran antar instansi vertikal dengan SKPD di daerah;

d. Inisiatif pengembangan HHBK harus diikuti oleh tahapan jelas mulai perencanaan, sosialisasi, strategi implementasi, proses monitoring termasuk mekanisme pemberian insentif disinsentif;

e. Rencana penyusunan kebijakan HHBK harus jelas konsep dengan memperhatikankeadilan antar wilayah yakni pengembangan wilayah bagian selatan dan wilayah bagian utara;

f. Institusi yang bertanggungjawab dalam merumuskan draf kebijakan HHBKberasal dari Dinas Kehutanan.Akan tetapi perlu adanya sinergidengan inisiatif yang dikembangkan oleh WWF Nusa Tenggara;

g. Dalam proses perumusan kebijakan pengelolaan HHBK, agar melibatkan unsur eksekutif. Pihak eksekutif juga mendukung dan berharap agar dilibatkan. Hal ini penting agar mendapatkan dukungan politik ke depan.

Temuan lapangan dari penelitian ini juga memperlihatkan bahwa terdapat permasalahan baik sosial maupun permasalahan hukum. Permasalahan sosial menyangkut tidak terakomodirnya sejumlah komoditi yang banyak diusahakan oleh masyarakat dalam Permenhut No.: P. 35/Menhut-II/2007 tentang HHBK. Seperti halnya 
di KLU, maka perlu dirumuskan solusi untuk menjamin kepastian hukum terhadap komoditas yang sudah ada. Dengan demikiandiperlukan pertimbangan dan kehati-hatian mengingat komoditas yang dominan ditanami masyarakat merupakan komoditas perkebunan yang selama ini cukup resisten dengan institusi kehutanan.Penentuan komoditas HHBK harus tetap mempertahankan karakteristik fisik, nilai dan fungsi hutan.

Permasalahan dari aspek hukum, pemerintah daerah belum sepenuhnya peduli dan juga belum memasukkan rumusan pengelolaan HHBK kedalam rencana strategis daerah atau produk legislasi daerah. Pemerintah daerah sebetulnya sudah sadar bahwa potensi HHBK cukup tinggi serta memberikan kemanfaatan sebesarbesar bagi rakyat khususnya di sekitar kawasan hutan.

Berdasarkan penjelasan di atas, langkah-langkah strategis yang harus dilakukan untuk mendorong lahirnya kebijakan pengelolaan HHBK yakni:

a. Perlunya percepatan pembentukan POKJA yang didalamnya melibatkan anggota legislatif. Peran dan struktur POKJA disiapkan oleh Dinas Kehutanan. POKJA bertugas untuk mempersiapkan dan mempercepat rencana pengelolaan HHBK, menetapkan produk HHBK unggulan daerah termasuk mengawal implementasi pengelolaan HHBK. Payung hukum pembentukan POKJA dilakukan melalui keputusan Bupati;

b. Perlunya penetapan manajemenperencanaan dan pengelolaan HHBK yang nantinya menjadi acuan diantara instansi teknis;

c. Materi muatan pengaturan produk kebijakan pengelolaan HHBK memuat:

- Aspek perencanaan;

- Mekanisme pemberian insentif dan disinsentif;

- Perijinan dan tata niaga HHBK dari hulu - hilir;

- Penerapan tekhnologi yang ramah lingkungan;

- Mekanisme koordinasi dan pembagian peran kelembagaan daerah dan instansi vertikal yang ada di daerah;

- Penguatan kelembagaan masyarakat melalui penerapan awiq-awiq - yaitu perangkat aturan yang didasarkan pada kearifan lokal.

\section{c. Kabupaten Timur Tengah Selatan (NTT)}

Kawasan Mutis merupakan hutan konservasi berupa kawasan cagar alam. Di dalam kawasan tersebut terdapat sejumlah komoditi HHBK yang dimungkinkan dapat dimanfaatkan oleh masyarakat, namun harus melalui ijin. Masyarakat banyak menggantungkan hidupnya dari produk HHBK. Akan tetapiakses dan pemanfaatan 
HHBK di wilayah tersebut cukup terbatas karena masyarakat tidak diperbolehkan menanam, menambah dan mengubah bentuk fisik kawasan tersebut.

Berdasarkan temuan di lapangan, terdapat empat jenis HHBK yang dapat memberikan manfaat ekonomi bagi masyarakat maupun devisa bagi pemerintah daerah. Keempat jenis HHBK tersebut yakni madu, bambu, kemiri dan empon-empon amat potensial dijadikan sebagai produk unggulan daerah. Penting untuk dipikirkan ke depannya, perlu ada penetapan komoditas unggulan agar secara yuridis dapat dijadikan rujukan atau referensi bagi stakeholders yang mengelola HHBK.

Seperti halnya di KLU dan Kabupaten Lombok Tengah, terdapat sejumlah komoditi yang banyak diusahakan oleh masyarakat namun tidak terakomodir dalam Permenhut No.: P. 35/Menhut-II/2007 tentang HHBK. Dengan demikian, perlu dirumuskan solusi untuk menjamin kepastian hukum terhadap komoditas yang selama ini banyak diusahakan oleh masyarakat dengan tetap mempertimbangkan karakteristik fisik, nilai dan fungsi kawasan.

Dalam kaitannya dengan inisiasi untuk mendorong regulasi pengelolaan HHHBK, respon stakeholders (Pemerintah Daerah, Eksekutif, Perguruan Tinggi, LSM dan masyarakat) cukup mendukung.Akan tetapi, sebelum menyusun produk kebijakan terlebih dahulu dilakukan inventarisasi dan identifikasi potensi HHBK di dalam dan di luar kawasan. Hal itu sebagai dasar untuk mensinkronkan dengan data dari SKPD terkait.

Berdasarkan temuan di lapangan, terdapat dua pendapat yang berkembang. Pertama, sebagian menginginkan agar kebijakan pengelolaan HHBK dimasukan dalam Peraturan Daerah (PERDA) Nomor 6 tahun 2012 tentang Jasa Lingkungan. Berdasarkan pendapat pertama ini, muncul opsi bahwa PERDA tersebut harus direvisi. Kedua, sebagian pihak mengusulkan agar kebijakan pengelolaan HHBK menjadi PERDA tersendiri, agar ruang lingkup pengaturannya lebih luas mulai dari aspek perencanaan, pengelolaan sampai tata niaga. Di samping itu, dalam materi muatan Perda harus jelas hadirnya pelibatan masyarakat termasuk peningkatan kapasitas kelembagaannya. Hal yang tidak kalah penting adalah dalam proses perumusannya perlu melibatkan para pihak yang lebih luas seperti pihak DPRD. Hal itu penting untuk mendapat dukungan politik.

Beberapa langkah-langkah strategis ke depan yang harus dilakukan untuk mendorong kebijakan pengelolaan HHBK yakni:

a. Perlunya mempercepat penetapan produk $\mathrm{HHBK}$ unggulan daerah;

b. Harus melibatkan para pihak untuk merumuskan kebijakan yang tepat antara menggabungkan kebijakan tentang HHBK itu dengan Perda jasa lingkungan atau menjadi Perda tersendiri. Berdasarkan hasil kajian, kebijakan yang tepat 
untuk mendorong regulasi HHBK dapat dilakukan dalam pengaturan terpisah dalam bentuk produk hukum tersendiri;

c. Materi muatan pengaturan produk kebijakan pengelolaan HHBK memuat:

- Aspek perencanaan dengan melibatkan parapihak termasuk anggota DPRD;

- Mengatur akses masyarakat dalam memanfaatkan HHBK di kawasan hutan baik di hutan lindung, hutan produksi dan kawasan konservasi;

- Mengatur dukunganinfrastruktur pemasaran;

- Mekanisme koordinasi dan pembagian peran kelembagaan daerah dan instansi vertikal yang ada di daerah;

- Penguatan kelembagaan masyarakat.

\section{Alternatif Kebijakan Pengelolaan HHBK}

Dalam perspektif hukum, fungsi hukum diartikan sebagai sebagai pengarah/direktif terhadap perkembangan masyarakat. ${ }^{8}$ Fungsi hukum juga dimaksudkan untuk menstrukturkan seluruh proses yang substansinya berada dan dilakukan oleh disiplin ilmu lain. ${ }^{9}$ Fungsi hukum sedemikian, menempatkan hukum tidak lagi dipandang atau menjalankan sebagai fungsi kontrol atau lebih bermakna represif semata, melainkan juga dapat berubah fungsi menjadi mengarahkan sekaligus menjadi bingkai yuridis atas dinamika perkembangan keilmuan sehingga memiliki ciri atau karakteristik normatif.Dalam konteks kajian pengembangan HHBK fungsi hukum menjadi bingkai yuridis (legal framework) terhadap hasil kajian disiplin ilmu kehutanan, pertanian, lingkungan, sosial dan ekonomi. Hasil kajian dari berbagai disiplin ilmu terhadap HHBK ternyata hanya memiliki nilai indikatif saja, artinya hanya sebagai pedoman secara teknis dan akademis namun tidak mengikat siapapun. Menjadi amatlah pentingbahwa hasil kajian dapat diarahkan untuk memiliki nilai normatif (mengikat). Hasil kajian perlu dituangkan kedalam produk hukum yang jelas dan mengikat untuk ditaati dan dipatuhi.

Dalam tertib hukum positif di Indonesia, sikap dan perilaku pemerintah/ administrasi Negara dalam melaksanakan sikap tindaknya harus mendasarkan diri pada peraturan perundang-undangan yang berlaku. Dalam sistem peraturan perundang-undangan, pemerintah harus taat asas, bahwa peraturan perundangundangan yang lebih rendah tidak boleh bertentangan dengan peraturan perundang-undangan yang lebih tinggi. Tegasnya, ada hirarkhi tata urutan peraturan perundang-undanganyang harus diperhatikan berikut materi muatan yang diaturnya.

\footnotetext{
${ }^{8}$ Sjachran Basah 2002.

${ }^{9}$ Mochtar Kusumaatmadja, 1978.
} 
Adapun dalam kaitannya dengan pilihan kebijakan dalam pengelolaan HHBK di daerah penelitian, ada beberapa rekomendasi produk hukum yang diusulkan sesuai dengan materi muatan yang diatur, mulai dari norma yang bersifat konkrit yakni keputusan atau penetapan (beschikking), seperti Keputusan Bupati; sampai norma yang bersifat umum yang bersifat mengatur (regeling) seperti: Peraturan Bupati, Peraturan Bupati dan Peraturan Daerah.Disamping alternatifrekomendasi kebijakan melalui produk hukum tingkat daerah, pengelolaan HHBK juga dapat dilakukan dengan merekomendasikan revisi terhadap Permenhut Nomor P.35/Menhut-II/2007 tentang Hasil Hutan Bukan Kayu.

\section{Pilihan Kebijakan I: Keputusan (Bupati) Kepala Daerah}

Keputusan Bupati atau Keputusan Kepala Daerah sebagai salah satu jenis peraturan perundang-undangan tingkat daerah, tidak secara tegas dan termuat dalam Undang-Undang Nomor 11 Tahun 2012 tentang Pembentukan Peraturan Perundang-undangan. Akan tetapi keberadaan Keputusan Bupati atau Keputusan Kepala Daerah tetap saja dapat diakui dan mempunyai kekuatan hukum mengikat sepanjang diperintahkan oleh peraturan perundangan yang lebih tinggi. Keputusan Bupati ini merupakan produk hukum yang legal yang diperoleh dari kewenangan bebas dari Pemerintah atau Administrasi Negara dalam melaksanakan sikap tindaknya menyelenggaraan urusan pemerintahan. Keputusan Bupati atau Keputusan Kepala Daerah dalam khasanah peraturan perundang-undangan sebenarnya tidak dapat dimasukkan dalam katagori norma hukum yang sifatnya mengatur dan berlaku mengikat umum. Keputusan Kepala Daerah lebih tepat jika dimasukkan kedalam kategori Ketetapan Tata Usaha Negara (Beschikking). Sifat dari substansi norma ketetapan adalah kongkrit, individual dan final.

Ketentuan Pasal 146 Undang-undang Nomor 32 Tahun 2004 tentang Pemerintah Daerah menegaskan:

(1) Untuk melaksanakan Peraturan Daerah dan atas kuasa Peraturan perundang-undangan, Kepala Daerah menetapkan Peraturan Daerah dan/atau Keputusan Kepala Daerah;

(2) Peraturan Kepala Daerah dan/atau Keputusan Kepala Daerah sebagaimana dimaksud Ayat (1) dilarang bertentangan dengan kepentingan umum, peraturan daerah dan peraturan perundangundangan yang lebih tinggi.

Terkait dengan pengelolaan HHBK di daerah, sekurang-kurangnya ada dua materi muatan yang perlu dituangkan dalam Keputusan Bupati atau Keputusan Kepala Daerah. Pertama, berkenaan dengan urgensi perlunya dibentuk Kelompok Kerja (Pokja) HHBK. Kedua, adalah perlunya penetapan komoditas unggulan HHBK di daerah.

Penetapan POKJA HHBK membutuhkan pengawalan yang melibatkan semua stakeholders yang relevan mulai dari inisiasi gagasan sampai lahirnya produk hukum. Disamping itu, pembentukan POKJA 
dimaksudkan untuk berperan mengakselerasi lahirnya produk kebijakan pengelolaan HHBK termasuk mempercepat penentuan produk unggulan daerah. Penetapan komoditas unggulan HHBK didasarkan atas pertimbangan bahwa ada sejumlah komoditas unggulan terdapat di dalam dan di luar kawasan hutan dan saat ini cukup banyak diusahakan oleh masyarakat. Akan tetapi belum ditetapkan dalam bentuk produk hukum tertentu yang bersifat mengikat bagi semua stakeholders di daerah.

Penetapan komoditas unggulan di daerah dapat dijadikan pedoman oleh stakeholders dalam pengelolaannya. Kemudian, penetapan tersebut juga dapat menjadi dasar dalam mengajukan pos anggaran (nomenklatur) sektor kehutanan di daerah.

\section{Pilihan Kebijakan II: Peraturan (Bupati) Kepala Daerah}

Secara terminologis makna peraturan kepala daerah merupakan jenis peraturan perundang-undangan tingkat daerah yang sifatnya adalah mengatur (regeling) dan bentuknya mengikat umum. Akan tetapi dalam praktek, mulai dari proses pembentukan sampai pengundangannya tidak dipergunakan istilah "peraturan kepala daerah", melainkan dipergunakan istilah berdasarkan cakupan wilayah keberlakuannya, seperti Peraturan Gubernur (tingkat propinsi) atau Peraturan Bupati/Walikota (Kabupaten/Kota).

Sebagai salah satu dari produk perundang-undangan tingkat daerah, kedudukan Peraturan Kepala Daerah dapat disejajarkan dengan Peraturan Daerah dan/atau di bawah Peraturan Daerah. Dikatakan dapat disejajarkan dengan Peraturan Daerah oleh karena produk hukum ini sifatnya mandiriartinya sepanjang belum ada Peraturan Daerah yang mengatur sesuatu persoalan di lingkungan masyarakat, maka Peraturan Kepala Daerah dapat dipergunakan sebagai sarana untuk mengatur kepentingan umum serta mengikat umum. Dikatakan di bawah Peraturan Daerah oleh karena Peraturan Kepala Daerah dikeluarkan untuk melaksanakan lebih lanjut ketentuan yang ada dalam Peraturan Daerah.

Keberadaan Peraturan Kepala Daerah sedemikian tertuang dalam Pasal 146 Ayat (1) Undang-Undang Nomor 32 Tahun 2004 tentang Pemerintahan Daerah yang menyatakan bahwa untuk melaksanakan Peraturan Daerah dan atas kuasa peraturan perundang-undangan, Kepala Daerah menetapkan Peraturan Kepala Daerah dan/atau Keputusan Kepala Daerah. Apabila ketentuan Pasal 146 Ayat (1) dikaitkan dengan teori perundang-undangan maka kehadiran Peraturan Kepala Daerah bersumber dari atribusi kewenangan maupun delegasi kewenangan. Jadi Peraturan Kepala Daerah dapat merupakan peraturan otonom maupun peraturan pelaksana

Dalam kaitannya dengan pengelolaan HHBK, hampir di beberapa lokasi penelitian tidak mempunyai cetak biru (blueprint) mengenai HHBK yang sesuai dengan kondisi lokal setempat.Secara nasional telah ada Peraturan Menteri Kehutanan (Permenhut) Nomor P.19/Menhut- 
II/2009 tentang Strategi Pengembangan Hasil Hutan Bukan Kayu Nasionalyang menjadi pedoman bagi penyusunan strategi pengembangan HHBK di daerah.Kendati sudah ada strategi HHBK nasional, tak urung dalam implementasinya di daerah acapkali mengalami kesulitan. Dibutuhkan strategi pengembangan HHBK di tingkat daerah yang bersifat komprehensif dan partisipatif, yang proses penyusunannya perlu melibatkan berbagai pihak yang berkepentingan. Perlu ada strategi khusus supaya pengembangan HHBK bersifat mengikat dan menjadi rujukan bagi setiap stakeholder yang berkepentingan, untuk itu strategi pengembangan HHBK di daerah tidak cukup hanya produk kajian teknis dan akademis semata. Strategi pengembangan HHBK di daerah perlu memperoleh bentuk hukum yang jelas sesuai dengan materi muatannya.

\section{Pilihan Kebijakan III: Peraturan Daerah}

Peraturan Daerah Tingkat Propinsi dan Peraturan Bupati/Walikotamerupakan dua jenis peraturan perundang-undangan tingkat daerah. Kedua jenis peraturan ini lahir sebagai konsekuensi diterapkannya otonomi daerah baik di tingkat provinsi maupun kabupaten/kota. Pasal 136 ayat (2) Undang-Undang Nomor 32 Tahun 2004 tentang Pemerintahan Daerah, menegaskan, bahwa "peraturan daerah dibentuk dalam rangka penyelenggaraan otonomi daerah provinsi/kabupaten/kota dan tugas pembantuan".

Otonomi daerah menurut Pasal 1 angka 5 Undang-Undanng Nomor 32 Tahun 2004 tentang Pemerintahan Daerah adalah hak, wewenang dan kewajiban daerah otonom untuk mengatur dan mengurus sendiri urusan pemerintahan dan kepentingan masyarakat setempat sesuai dengan peraturan perundang-undangan. Urusan pemerintahan yang dimaksud di dalam rumusan Pasal di atas adalah fungsi-fungsi pemerintahan yang menjadi hak dan kewajiban setiap tingkatan dan/atau susunan pemerintahan untuk mengatur dan mengurus fungsi-fungsi tersebut yang menjadi kewenangannya dalam rangka melindungi, melayani, memberdayakan dan mensejahterakan masyarakat.

Dari pengertian tersebut, materi muatan peraturan daerah (baik Propinsi maupun Kabupaten/Kota) pada hakikatnya tidak lain mengatur urusan-urusan pemerintahan yang sudah diserahkan kepada daerah. Kecuali urusan-urusan pemerintahan yang secara strategis tetap menjadi urusan pemerintah pusat, seperti politik luar negeri, pertahanan keamanan, yustisi, moneter dan fiskal nasional dan agama. Urusan urusan pemerintahan meliputi urusan wajib dan urusan pilihan. Soehino, mengemukakan bahwa materi yang diatur dalam peraturan daerah, meliputi:

1. Materi-materi atau hal-hal yang memberi beban kepada penduduk, misalnya pajak dan retribusi daerah;

2. Materi-materi atau hal-hal yang mengurangi kebebasan penduduk, misalnya mengadakan larangan-larangan dan 
kewajiban-kewajiban yang biasanya disertai ancaman atau sanksi pidana;

3. Materi-materi atau hal-hal yang membatasi hak-hak penduduk, misalnya penertiban garis sempadan

4. Materi-materi atau hal hal yang telah ditentukan dalam peraturan perundang-undangan yang sederajad dan tingkatannya lebih tinggi, harus diatur dengan peraturan daerah.

Disamping materi muatan di atas, menurut Pasal 136 ayat (3) Undang-Undang Nomor 32 Tahun 2004 tentang Pemerintahan Daerah, Peraturan Daerah juga merupakan penjabaran lebih lanjut dari peraturan perundang-undangan yang lebih tinggi dengan memperhatikan ciri khas masing-masing daerah. Ketentuan Undang-Undang nomor 32 tahun 2004 tentang Pemerintahan Daerah yang terkait dengan keberadaan peraturan daerah tersebut selaras dengan ketentuan Pasal 12 Undang-Undang Nomor 11 Tahun 2012 tentang Pembentukan Peraturan Perundangundangan yang menyatakan bahwa materi muatan peraturan daerah adalah seluruh materi muatan dalam penyelenggaraan otonomi dan tugas pembantuan dan menampung kondisi khusus daerah serta penjabaran lebih lanjut dari peraturan perundang-undangan yang lebih tinggi. Secara lebih spesifik, materi muatan peraturan daerah pada dasarnya berisi dua hal. Pertama, menyangkut hak dan kewajiban dari pemegang peran (subyek sekaligus obyek) dari peraturan tersebut. Kedua, memuat tugas, wewenang dan kewajiban badan pelaksana yang akan melaksanakan dan menegakkan peraturan tersebut.

Terkait dengan pengelolaan HHBK di daerah, ada beberapa temuan materi muatan yang perlu dituangkan dalam peraturan daerah. Dapat disebutkan antara lain yang berkenaan dengan gagasan perlunya mengatur norma perilaku pemegang peran (stakeholder) dalam pengelolaan tata niaga HHBK mulai dari hulu sampai hilir di lokasi penelitian: pengaturan mengenai hak, kewajiban, wewenang, tugas dan tanggungjawab dari masing-masing pemegang peran; pengaturan mekanisme pemberian insentif dan disinsentif; pengaturan mengenai mekanisme koordinasi dan kemitraan antara pemegang peran; pengaturan jaringan pemasaran produk HHBK; pengaturan mengenai perizinan dan tata niaga HHBK. Kesemua materi muatan tersebut merupakan materi yang perlu dituangkan dalam peraturan daerah.

Pilihan untuk mempergunakan jenis peraturan perundang-undangan, apakah dengan menerbitkan Keputusan Kepala daerah atau Peraturan Kepala Daerah sangat tergantung dari cakupan ruang lingkup substansinya. Apabila suatu peraturan daerah atau peraturan perundangundangan memberi kuasa untuk penjabaran lebih lanjut dalam peraturan pelaksana di tingkat daerah yang cakupan substansinya bersifat khusus bahkan bisa dikatakan sempit maka jenis Keputusan Kepala Daerah yang dapat direkomendasikan. Apabila substansi cakupannya lebih luas dan 
menyangkut berbagai sektor maka lebih tepat jika diatur dalam Peraturan Kepala Daerah.

Dengan mendasarkan kepada kerangka yuridis peraturan perundangundangan pada sub bahasan 6.1 - 6.3 dikaitkan dengan kondisi empiris keberadaan HHBK di lokasi penelitian, dapat ditentukan beberapa alternatif kebijakan pengelolaan HHBK sebagaimana matriks di bawah: 


\begin{tabular}{|c|c|c|c|c|c|}
\hline No & Pilihan Kebijakan & Argumentasi & Rekomendasi & Tujuan & Bentuk Hukum \\
\hline 1 & $\begin{array}{l}\text { Pembentukan } \\
\text { Kelompok Kerja } \\
\text { (POKJA) }\end{array}$ & $\begin{array}{l}\text { Pengelolaan HHBK membutuhkan } \\
\text { pengawalan yang melibatkan semua } \\
\text { stakeholder yang relevan mulai dari } \\
\text { inisiasi gagasan sampai lahirnya } \\
\text { produk hukum. }\end{array}$ & $\begin{array}{l}\text { Penetuan tim Pokja melibatkan } \\
\text { unsur SKPD terkait, Unsur } \\
\text { DPRD, LSM, Perguruan Tinggi } \\
\text { dan unsurmasyarakat }\end{array}$ & $\begin{array}{l}\text { POKJA berperan untuk } \\
\text { mengakselerasi lahirnya } \\
\text { produk kebijakan } \\
\text { pengelolaan HHBK } \\
\text { termasuk mempercepat } \\
\text { penentuan produk unggulan } \\
\text { daerah }\end{array}$ & $\begin{array}{l}\text { Keputusan Bupati } \\
\text { tentang pembentukan } \\
\text { Kelompok Kerja } \\
\text { (POKJA) HHBK }\end{array}$ \\
\hline 2 & $\begin{array}{l}\text { Penetapan } \\
\text { komoditas } \\
\text { unggulan di } \\
\text { masing-masing } \\
\text { lokasi penelitian }\end{array}$ & $\begin{array}{l}\text { Ada sejumlah komoditas unggulan } \\
\text { terdapat di dalam dan di luar } \\
\text { kawasan hutan dan saat ini cukup } \\
\text { banyak diusahakan oleh } \\
\text { masyarakat. Namun sejumlah } \\
\text { komoditas unggulan tersebut, } \\
\text { belum ditetapkan dalam bentuk } \\
\text { produk hukum tertentu yang } \\
\text { bersifat mengikat bagi semua } \\
\text { stakeholder. }\end{array}$ & $\begin{array}{l}\text { - Penentuan komoditas unggulan } \\
\text { ditetapkan berdasarkan } \\
\text { karakteristik lokal. } \\
\text { - Proses perumusandan penetapan } \\
\text { komoditas unggulan daerah } \\
\text { perlu dilakukan melalui } \\
\text { penjaringan aspirasi masyarakat } \\
\text { serta didahului oleh pengkajian } \\
\text { secara komprehensif. }\end{array}$ & $\begin{array}{l}\text { - Dapat dijadikan pedoman } \\
\text { oleh para stakeholder } \\
\text { dalam pengelolaannya } \\
\text { - Menjadi dasar dalam } \\
\text { mengajukan pos } \\
\text { anggaran } \\
\text { (nomenklatur)sektor } \\
\text { kehutanan di daerah. }\end{array}$ & $\begin{array}{l}\text { Keputusan Bupati } \\
\text { tentang penetapan } \\
\text { komoditas unggulan } \\
\text { HHBK }\end{array}$ \\
\hline 3 & $\begin{array}{l}\text { Pengaturan grand } \\
\text { strategi HHBK di } \\
\text { Daerah }\end{array}$ & $\begin{array}{l}\text { - Peraturan Menteri Kehutanan } \\
\text { Republik Indonesia Nomor } \\
\text { P.19/Menhut-Ii/2009 Tentang } \\
\text { Strategi Pengembangan Hasil } \\
\text { Hutan Bukan Kayu Nasional } \\
\text { masih bersifat umum dan kurang } \\
\text { kurang operasional } \\
\text { - Ada peluang yuridis dalam } \\
\text { bentuk produk hukum local } \\
\text { sebagai mandate dari peraturan } \\
\text { perundang-undangan yang lebih } \\
\text { tinggi untuk membentuk strategi }\end{array}$ & 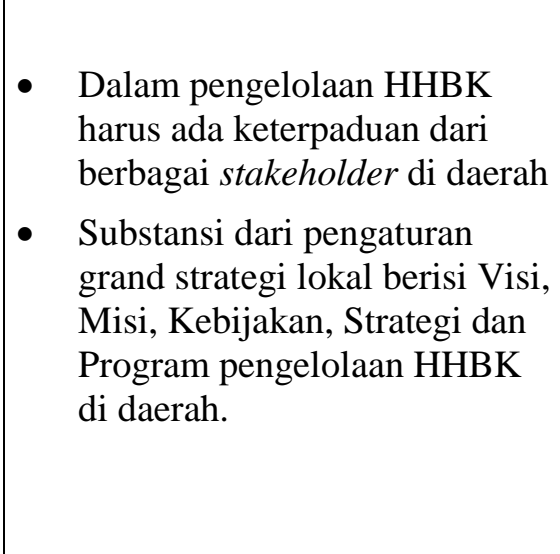 & $\begin{array}{l}\text { Menjadi acuan bagi } \\
\text { stakeholder dalam } \\
\text { pengelolaan HHBK di } \\
\text { daerah. }\end{array}$ & $\begin{array}{l}\text { Peraturan Bupati } \\
\text { tentang strategi } \\
\text { HHBK di daerah }\end{array}$ \\
\hline
\end{tabular}




\begin{tabular}{|c|c|c|c|c|c|}
\hline No & Pilihan Kebijakan & Argumentasi & Rekomendasi & Tujuan & Bentuk Hukum \\
\hline & & HHBK di tingkat lokal & & & \\
\hline 4 & $\begin{array}{l}\text { Kemitraan dan } \\
\text { Pengelolaan Tata } \\
\text { Niaga HHBK }\end{array}$ & $\begin{array}{l}\text { - Potensi HHBK cukup banyak di } \\
\text { dalam dan di luar kawasan hutan. } \\
\text { Saat ini menjadi sumber ekonomi } \\
\text { masyarakat di sekitar kawasan } \\
\text { hutan. } \\
\text { - Pengelolaan HHBK cukup } \\
\text { kompleks sehingga memerlukan } \\
\text { kemitraan yang melibatkan } \\
\text { berbagai stakeholder sehingga } \\
\text { perlu pengaturan norma prilaku, } \\
\text { berkenaan dengan apa tugas dan } \\
\text { tanggungjawab, siapa melakukan } \\
\text { apa, hak dan kewajiban masing- } \\
\text { masing stakeholder. } \\
\text { - Dengan pengaturan produk } \\
\text { HHBK diharapkan dapat menjadi } \\
\text { solusi untuk mengurangi tingkat } \\
\text { kemiskinan masyarakat yang } \\
\text { tinggal di sekitar kawasan hutan }\end{array}$ & $\begin{array}{l}\text { Penyusunan naskah akademik } \\
\text { pengelolaan HHBK yang materi } \\
\text { muatan meliputi aspek } \\
\text { perencanaan, perijinan dan tata } \\
\text { niaga HHBK, mekanisme } \\
\text { pemberian insentif dan disinsentif, } \\
\text { penerapan tekhnologi yang ramah } \\
\text { lingkungan, mekanisme } \\
\text { koordinasi dan pembagian peran } \\
\text { kelembagaan daerah dan instansi } \\
\text { vertikal yang ada di daerah, } \\
\text { penguatan kelembagaan } \\
\text { masyarakat (melalui } a w i q-a w i q), \\
\text { dan pengaturan jaringan } \\
\text { pemasaran produk HHBK }\end{array}$ & $\begin{array}{l}\text { - Ada jaminan kepastian } \\
\text { hukum dan kepastian } \\
\text { usaha oleh masyarakat } \\
\text { dalam pengelolaan } \\
\text { HHBK } \\
\text { - Menjadi dasar dalam } \\
\text { mengajukan pos } \\
\text { anggaran (nomenklatur) } \\
\text { yang bersumber dari } \\
\text { APBD dan sumber } \\
\text { lainnya. }\end{array}$ & $\begin{array}{l}\text { Peraturan Daerah } \\
\text { (PERDA) }\end{array}$ \\
\hline 5 & $\begin{array}{l}\text { Usulan Revisi } \\
\text { PermenhutNomor : } \\
\text { P.35/ Menhut- } \\
\text { II/2007 tentang } \\
\text { Hasil Hutan Bukan } \\
\text { Kayu }\end{array}$ & $\begin{array}{l}\text { - Sejumlah komoditas unggulan } \\
\text { daerah belum terakomodir dalam } \\
\text { lampiran Permenhut No.: P. } \\
\text { 35/Menhut-II/2007 yang secara } \\
\text { empirik menjadi unggulan daerah } \\
\text { - Ada peluang secara yuridis } \\
\text { melakukan revisi terhadap } \\
\text { lampiran Permenhut dengan } \\
\text { merivisi peraturan dasarnya. Oleh } \\
\text { karena lampiran tersebut }\end{array}$ & $\begin{array}{l}\text { - Usulan revisi Permenhut No.: P. } \\
\text { 35/Menhut-II/2007 dapat } \\
\text { dilakukan melalui proses } \\
\text { executive review. } \\
\text { - } \quad \text { Untuk mendorong proses } \\
\text { eksekutif review terhadap } \\
\text { permenhut No.: P. 35/Menhut- } \\
\text { II/2007, daerah dapat } \\
\text { mengajukan usulan komoditas } \\
\text { unggulan daerah yang tidak }\end{array}$ & $\begin{array}{l}\text { Melahirkan produk } \\
\text { kebijakan yang responsive } \\
\text { dan populis. }\end{array}$ & $\begin{array}{l}\text { Peraturan Menteri } \\
\text { Kehutanan }\end{array}$ \\
\hline
\end{tabular}




\begin{tabular}{|l|l|l|l|l|}
\hline No & Pilihan Kebijakan & Argumentasi & Rekomendasi & Bentuk Hukum \\
\hline & & $\begin{array}{l}\text { merupakan bagian yang tidak } \\
\text { terpisahkan dari peraturan } \\
\text { dasarnya. }\end{array}$ & $\begin{array}{l}\text { terakomodir dalam Permenhut } \\
\text { tersebut. }\end{array}$ & \\
\hline
\end{tabular}

\section{Penutup}

\section{Simpulan}

Dari temuan hasil kajian normatif maupun empiris dapat dikemukakan beberapa simpulan sebagai berikut:

a. Bahwa HHBK sampai saat ini belum sepenuhnya menjadi kepedulian (concern) di daerah penelitian walaupun disadari bahwa potensi HHBK cukup tinggi serta memberikan kemanfaatan sebesar-besar bagi rakyat khususnya di sekitar kawasan hutan. Indikasi ini terlihat bahwa kebijakan HHBK belum dituangkan dalam produk legislasi di daerah dan/atau rencana strategis kabupaten/kota

b. Alternatif kebijakan dalam pengelolaan HHBK dapat dilakukan secara berjenjang mulai dari norma yang paling konkrit sampai pada norma yang bersifat umum dan abstrak. Norma hukum yang bersifat konkrit yaitu keputusan atau penetapan (Beschikking) diwujudkan dalam Keputusan Bupati. Peraturan yang bersifat abstrak dan umum dituangkan dalam bentuk pengaturan (Regeling) seperti Peraturan Bupati dan Peraturan Daerah.

c. Masyarakat pro aktif dalam mendorong lahirnya produk kebijakan pengelolaan HHBK yang responsif. Disamping oleh karena adanya kesadaran masyarakat atas tingginya nilai ekonomi dan kemanfaatan HHBK bagi masyarakat, produk kebijakan HHBK dibutuhkan sebagai jaminan atas kepastian hukum dan kepastian usaha.

\section{Saran}

Berdasarkan kesimpulan di atas, beberapa kegiatan yang menjadi saran dan tindak lanjut ke depan meliputi:

a. Perlunya menginisiasi dan memfasilitasi pembentukan POKJA pengelolaan HHBK yang didalamnya memuat peran dan tugas masing-masing stakeholders;

b. Memfasilitasi penetapan produk komoditi unggulan yang sesuai dengan karakteristik di masing-masing daerah;

c. Memfasilitasi tersusunnya Peraturan Bupati tentang arah, strategi, kebijakan dan program pengembangan HHBK di daerah; 
d. Memfasilitasi penyusunan peraturan daerah (PERDA) tentang pengembangan HHBK yang substansinya mengatur norma perilaku stakeholder yang terlibat dalam pengelolaan HHBK;

e. Pentingnya pengawalan implementasi peraturan daerah (PERDA) tentang pengembangan $\mathrm{HHBK}$;

f. Pentingnya merumuskan mekanisme kemitraan dan koordinasi antar institusi vertikal dan horisontal dalam mengimplementasikan pengelolaan HHBK. 


\section{Daftar Pustaka}

Basah, Sjachran. Tiga Tulisan Tentang Hukum, Bandung: Alumni, 1992.

Kusumaatmadja, Mochtar, Fungsi Hukum dalam Pembangunan, Bandung: Bina Cipta, 1978.

Muktasam, A. "Regulating The Commons: Participatory And Multistakeholder Approaches?", a paper presented at Seminar Nasional dan Pameran Hasil-hasil Penelitian" pada Lembaga Penelitian - Universitas Mataram, Mataram, 29 - 30 September, 2009.

Hadjon, Philipus M. Administration Law in Indonesia, Malang: Airlangga University Press, 2000.

Soerjono, Soekanto, dan Sri Mamoedji, Penelitian Hukum Normatif, Jakarta: Rajawali Press, 1999.

Syafrudin, Ateng. Penataan Ruang dan Lingkungan Hidup, Kaitannya dengan Wewenang Pemerintah Daerah dalam hal Perizinan, Bandung, 1995.

Wibowo, Gatot Dwi Hendro. Identifikasi Pemetaan Konflik Sumberdaya Hutan di NTB, Kerjasama Pusat Penelitian Pengembangan Perdesaan (P3P) Unram dengan Badan Perencanaan Pembangunan Nasional (Bappeda) Provinsi NTB, 2002.

, Sinkronisasi Kewenangan Penyelenggaraan Urusan di bidang Kehutanan di Propinsi NTB, Kerjasama Fakultas Hukum Universitas Mataram dengan Badan Perencanaan Pembangunan Daerah (Bappeda) Provinsi NTB, 2003.

Penyelesaian Sengketa Hutan (Studi Kasus Implementasi Hutan Kemasyarakatan di Kawasan Hutan Lindung Sesaot Lombok Barat (Ketua Tim Peneliti), Dibiayai dana DIPA PNBP Universitas Mataram Tahun 2010, Tanggal 31 Desember 2009.

, "Fungsi Hukum dalam Pengelolaan Sengketa Sumberdaya

Hutan, Kajian Masalah Hukum dan Pembangunan Perspektif Publish or Perish", Majalah Ilmiah Fak Hukum Universitas Wijaya Kusuma Surabaya Vol. VI Nomor 1 Tahun 2001, ISSN: 1410 - 3648.

, Cita Hukum Pancasila untuk Pengelolaan Sumberdaya Alam, Orasi Ilmiah dalam rangka Dies Natalis Universitas Mataram, Tahun 2008. 